\title{
Hambatan guru dalam pembelajaran daring: \\ Studi kasus di kelas V MIN 2 Kota Mataram
}

\author{
${ }^{1}$ Muhamad Ahyar Rasidi, ${ }^{2}$ Nurrismi Hikmatullah, ${ }^{3}$ M. Sobry \\ 1ahyarrasidi@uinmataram.ac.id \\ 1,2,3Pendidikan Guru Madrasah Ibtidaiyah, Fakultas Tarbiyah dan Keguruan, \\ UIN Mataram
}

\begin{abstract}
ABSTRAK
Penelitian ini bertujuan untuk menginvestigasi dan mendeskripsikan hambatan pembelajaran daring di kelas V MIN 2 Kota Mataram. Penelitian ini menggunakan studi kasus dengan dengan mengeksplorasi informasi dari 2 guru dan 5 peserta didik sebagai subjek penelitian. Adapun teknik pengumpulan data menggunakan wawancara, observasi, dan dokumentasi. Hasil penelitian menggambarkan bahwa terdapat berbagai hambatan guru dalam menerapkan pembelajaran daring diantaranya: (1) implementasi perangkat pembelajaran yang disusun belum dapat diimplementasikan secara optimal, termasuk pemanfaatan e-learning dalam pembelajaran. (2) Keterbatasan kuota internet dan handphone android peserta didik. Adapun strategi antisipasinya, guru menggunakan flatform media sosial lainnya sebagai media pembelajaran. Adapun cara mengatasi hambatan tersebut dilakukan dengan berbagai tindakan nyata seperti: (1) penyediaan kuota internet gratis, (2) pendampingan dan pelatihan e-learning, dan (3) pembagian ponsel gratis. Ditambah dengan penyajian materi pembelajaran yang menarik dan peningkatan motivasi belajar peserta didik secara berkelanjutan.
\end{abstract}

Kata kunci: hambatan guru, pembelajaran daring, studi kasus

\section{Teachers' barriers in online learning:}

\section{A case study in $5^{\text {th }}$ grade students of MIN 2 Kota Mataram}

\begin{abstract}
This study aimed to investigate and describe the barriers to online learning in class V MIN 2 Mataram City. This research used a case study by exploring information from 2 teachers and 5 students as research subjects. The results of the study illustrated that there were various obstacles for teachers in implementing online learning including (1) the implementation of the learning tools that have been prepared could not be implemented optimally, including the use of e-learning; (2) limited internet quota and student android mobile phones. As for the anticipation, the teachers used other social media platforms as learning media. The way to overcome these obstacles is carried out by various concrete actions such as (1) providing free internet quota, (2) e-learning assistance and training, and (3) distribution of free mobile phones, plus the presentation of interesting learning materials and improvement of student learning motivation on an ongoing basis.
\end{abstract}

Keywords: teacher barriers, online learning, case study 


\section{PENDAHULUAN}

Status pandemi Covid-19 ditetapkan sebagai pandemi global oleh World Health Organization (WHO) pada tanggal 11 Maret 2020. Hal ini didasarkan pada sebaran kasus di 114 negara. Gejala Covid-19 mirip seperti flu yang disertai dengan pneumonia (radang paru), yang berdampak pada pasien sulit bernafas (Protokol Percepatan Penanganan Pandemi Covid-19 (Corona Virus Disease 2019), 2019). Semua manusia berpotensi terjangkiti dan perlu diantisipasi agar penyebarannya tidak meluas. Salah satu bentuk tindakan antisipatif dalam mengatasi penyebarannya adalah dengan melakukan kampanye massal, tinggal di rumah saja dan menjaga jarak (Rigianti, 2020).

Masifnya penyebaran Covid-19 berdampak pada berbagai aspek kehidupan, termasuk pada dunia pendidikan. Sistem pendidikan secara normal biasanya dilaksanakan secara tatap muka, namun dengan adanya pandemi, haluan penyelenggaraan sistem pendidikan menjadi sistem daring disemua jenjang pendidikan. Transisi pola penyelenggaraan sistem pendidikan memunculkan berbagai persoalan pembelajaran, mengingat hal ini terjadi secara mendadak tanpa adanya persiapan sebelumnya (Asrul \& Ranti, 2020).

Mengacu pada Surat Edaran Menteri Pendidikan dan Kebudayaan Nomor 4 Tahun 2020 tentang Pelaksanaan Kebijakan Pendidikan dalam Masa Darurat Penyebaran Covid-19. Keputusan pemerintah terhadap dunia pendidikan salah satunya dengan meliburkan atau mereschedule pembelajaran berbasis rumah. Hal ini menimbulkan ketidaksiapan dalam melaksanakan pembelajaran daring. Sumber daya manusia yang masih sangat rendah terutama para pendidik di daerah tertinggal, jangkauan jaringan internet yang sangat sulit untuk diakses, dan juga kuota internet yang kian mahal. Walaupun teknologi sudah dimiliki dan tersedia di depan mata, namun jika akses jaringan internet kurang memadai sangat mempersulit proses pembelajaran (Sudarsana, 2020).

Pembelajaran adalah proses interaksi antara peserta didik dengan pendidik, sumber belajar dengan lingkungan belajar. Pembelajaran merupakan bantuan yang diberikan pendidik agar dapat terjadi proses perolehan ilmu dan pengetahuan, penguasaan kemahiran dan tabiat, serta pembentukan sikap dan kepercayaan pada peserta didik (Suardi, 2018). Dengan kata lain, pembelajaran merupakan proses untuk membantu peserta didik agar dapat belajar dengan baik (Tim PGSD C, 2017). Untuk itu, pembelajaran membutuhkan kurikulum yang baik. 
Kurikulum merupakan program pendidikan yang disediakan oleh lembaga pendidikan bagi para peserta didik. Melalui kurikulum, guru dapat mengeksplorasi aktivitas guru dan peserta didik. Kurikulum yang disusun dapat mendorong pertumbuhan dan perkembangan peserta didik sesuai dengan tujuan pendidikan yang ingin dicapai (Lismina, 2018), termasuk kurikulum yang berorientasi pada kurikulum pembelajaran sistem daring.

Pembelajaran yang dilakukan secara daring adalah proses belajar mengajar dengan cara yang baru yang menggunakan berbagai perangkat yang sepenuhnya membutuhkan jaringan internet. Pembelajaran daring adalah strategi terbaik untuk memastikan transfer of knowledge peserta didik paling tepat di masa pandemi (Rigianti, 2020). Kondisi ini memunculkan ketidaksiapan pembelajaran padahal kesiapan sebagai refresentasi kedisiplinan yang dapat meningkatkan prestasi belajar peserta didik (Malik \& Afandi, 2020). Perubahan yang terjadi secara cepat dan mendadak sebagai akibat penyebaran Covid-19 membuat semua orang dipaksa untuk melek teknologi. Melalui teknologi inilah satu-satunya jembatan yang dapat menghubungkan guru dan peserta didik dalam pembelajaran tanpa harus melakukan tatap secara langsung.

Pembelajaran daring dikembangkan dengan berbagai komponen seperti video, audio dan gambar. Kesemuanya mengkombinasikan berbagai keterampilan membaca, menulis, menyimak dan berbicara. Video pembelajaran diciptakan semenarik mungkin dan dikemas dengan penyesuaian kondisi dan karakteristik peserta didik sehingga materi pembelajaran tersebut dekat dengan peserta didik, maka tujuan pembelajaran dapat tercapai meskipun dalam kegiatan daring. Pembelajaran dengan daring sejatinya menuntut guru untuk menggunakan berbagai fitur pembelajaran termasuk media youtube yang dapat mendukung keberhasilan belajar peserta didik (Widyantara \& Rasna, 2020).

Pembelajaran dalam jaringan bukan hal yang baru dikenal dan diterapkan di dalam pendidikan pada saat ini. Konsep pembelajaran ini sudah ada sejak mulai bermunculan berbagai jargon berawalan $e$, seperti e-book, e-learning, e-laboratory, $e$ education, e-library, e-payment, dan lain sebagainya. Namun pada pelaksanaannya, pengguna aplikasi jauh lebih sedikit (Handika, 2020).

Hasil penelaahan berbagai literatur menyoroti temuan yang beragam tantangan pembelajaran daring diantaranya adalah tantangan dalam mendesain pembelajaran (Rasheed et al., 2020) dan kurangnya keterampilan pengaturan diri anak. Persiapan guru terbatas di kelas (Safford et al., 2016); resistensi terhadap 
gangguan teknologi (Brown, 2016). Tantangan lain yang menjadi kendala dalam pembelajaran daring adalah perangkat teknologi informasi, seperti HP android/computer/laptop dan kemampuan awal peserta didik yang heterogen (Rimbarizki \& Susilo, 2017; Wicaksono \& Rachmadyanti, 2017). Pengetahuan awal mahapeserta didik tentang aplikasi dalam HP android, dan cara mengoperasikannya sangat berpengaruh dalam pembelajaran daring.

Dari temuan di atas, kendala lainnya adalah kompetensi guru dalam mengoperasikan pembelajaran daring tidak seragam, termasuk penguasaan teknologi. Koneksi internet terkendala oleh provider jaringan, ditambah dengan aktivitas anak belajar mandiri tanpa pendampingan orang tua, karena sebagian orang tua tidak memiliki pengetahuan dan pendidikan yang memadai, kecendrungan anak pada aktivitas lain seperti bermain game saat dan setelah pembelajaran daring, membosankan karena videonya kurang interaktif dan menarik (Jamad, 2020). Bukan itu saja, terdapat kendala bagi guru dalam mengontrol proses pembelajaran, pembelajaran monoton ditambah racikan hasil produk yang dikembangkan guru kurang menarik (Zulkifli et al., 2020).

Implementasi pembelajaran daring di MIN 2 Kota Mataram berjalan cukup baik, namun kurang efektif dikarenakan waktu pembelajaran yang tidak cukup. Ada beberapa hal yang menjadi hambatan-hambatan bagi guru dalam menerapkan pembelajaran daring yaitu guru diharuskan untuk membuat video pembelajaran setiap hari dengan materi pembelajaran yang berbeda-beda, dan guru merancang video pembelajaran semanarik mungkin, agar peserta didik mudah memahami pembelajaran dengan baik. Kemudian guru mengirimkan video pembelajaran melalui aplikasi Whatsapp yang sebelumnya sudah dibuatkan grup pembelajaran untuk kelas V A. Selain itu guru harus memantau peserta didik setiap saat dengan menggunakan aplikasi WhatsApp dan menanyakan materi apa saja yang belum dipahami oleh peserta didik.

Beragam terobosan dan inovasi bidang pendidikan ditengah pandemi. Guru memastikan proses belajar mengajar berjalan dengan baik, walaupun pelaksanaannya di rumah. Inovasi pembelajaran merupakan solusi yang perlu dikembangkan, didesain, dan dilaksanakan oleh guru dengan mengoptimalkan media pembelajaran jarak jauh. Guru juga dapat menggunakan beragam metode pembelajaran e-Learning, berbasis teknologi informasi seperti komputer, HP dan lain sebagainya. Selanjutnya dapat menggunakan berbagai platform seperti Whatsapp, Google Classroom dan aplikasi lainnya (Jamad, 2020). Pada prosesnya 
inovasi pembelajaran di rumah juga di dukung oleh berbagai sumber daya manusia (Khurriyati et al., 2021).

Selain itu, guru dapat memberikan alternatif penugasan secara terstruktur sehingga pembelajaran sehari-hari dengan peserta didik bisa terselenggara secara bertahap. Inovasi lainnya adalah memastikan proses pembelajaran tetap berjalan, mendapatkan ilmu sesuai dengan panduan kurikulum, dan yang terpenting peserta didik selamat dan aman dari ancaman virus Covid-19. Salah satu cara yang juga bisa dilakukan adalah, guru bisa mengunjung peserta didik dari rumah ke rumah untuk memastikan anak betul-betul belajar di rumah tentunya dengan tetap memperhatikan protokol kesehatan yang ditetapkan.

Berdasarkan hasil penelaahan berbagai literatur dan observasi di atas, dapat menjadi informasi awal tentang hambatan guru dalam melaksanakan pembelajaran daring, hambatan apa yang mendominasi dan bagaimana guru mengatasi hambatan tersebut. Pada artikel ini diungkap secara mendalam kendala-kendala tersebut. Peneliti memfokuskan pada kelas V dengan judul penelitian "Hambatan Guru Dalam Penerapan Pembelajaran Daring Di Kelas V MIN 2 Kota Mataram".

\section{METODE PENELITIAN}

Penelitian ini merupakan kualitatif dengan pendekatan studi kasus (Chaedar, 2015). Penelitian ini berlangsung di MIN 2 Kota Mataram tahun pelajaran 2020/2021. Data yang dikumpulkan berupa kata-kata atau tindakan untuk mendeskripsikan fenomena yang terjadi pada subyek penelitian secara menyeluruh guna mendalami hambatan guru dalam pembelajaran daring. Adapun sumber data dalam penelitian ini terdiri atas sumber data primer dan sekunder. Sumber data primer yaitu dengan mewawancarai 2 guru dan lima peserta didik. Sedangkan data sekunder dengan melakukan pengamatan pada aktivitas pembelajaran daring. Adapun teknik pengumpulan data menggunakan observasi, wawancara dan dokumentasi. Selanjutnya, data yang ada dianalisa mengacu pada teknik analisis Miles and Huberman yang mencakup data reduction, display data, dan penarikan kesimpulan yang kemudian dikonfirmasi melalui triangulasi (Afrizal, 2016).

\section{HASIL DAN PEMBAHASAN}

\section{Hambatan guru dalam pembelajaran daring di MIN 2 Kota Mataram}

Kagiatan belajar melalui daring memiliki beberapa hambatan untuk peserta didik tetap belajar seperti biasa. Beberapa hambatan tersebut adalah keterbatasan 
penguasaan teknologi informasi oleh guru dan peserta didik, sarana dan prasarana yang kurang memadai, akses internet yang terbatas, serta kurang siapnya anggaran. Hambatan-hambatan itulah yang pada akhirnya memberikan dampak negatif bagi kualitas pendidikan di Indonesia (Kustiana, dkk, 2021). Selain itu, akses Pendidikan yang mudah namun ditengah pandemic yang serba susah mengakibatkan pembiayaan Pendidikan semakin mahal dan semakin bagi keluarga yang tidak memiliki pendapatan tetap (Kusumadewi, 2015).

Pada penelitian ini dilakukan pengamatan dan wawancara mendalam guna mengeksplorasi tantangan guru dalam berbagai aspek pembelajaran di antaranya yaitu perencanaan, pelaksanaan atau proses pembelajaran dan evaluasi tugas pembelajaran daring secara daring. Lebih jelasnya diuraikan di bawah ini:

\section{Perencanaan pembelajaran daring di MIN 2 Kota Mataram}

Perencanaan berasal dari kata "rencana" yang berarti pengambilan keputusan untuk mencapai tujuan. Menurut Ely dikutip dari Sanjaya mengatakan bahwa perencanaan itu pada dasarnya suatu proses dan cara berpikir yang dapat membantu menciptakan hasil yang diharapkan (Nasution et al., 2020). Rencana pelaksanaan pembelajaran (RPP) adalah rencana kegiatan pembelajaran tatap muka untuk satu kali pertemuan atau lebih. RPP dikembangkan dari silabus untuk mengarahkan kegiatan pembelajaran peserta didik dalam upaya kompetensi dasar (KD). Demikian juga perencanaan pembelajaran adalah buah dari perenungan mendalam tentang rencana aksi yang akan dilaksanakan.

MIN 2 Kota Mataram sebagai madrasah negeri yang tertib administrasi, selalu Menyusun perangkat pembelajaran sebelum mengajar. RPP yang disusun berdasar pada kondisi madrasah yang ada yaitu RPP daring. Hal ini karena kondisi madrasah yang tidak menyelenggarakan pembelajaran secara tatap muka. Konstruksi RPP daring dengan RPP tatap muka tidak jauh berbeda, RPP daring adalah rencana pelaksanaan pembelajaran yang dilakukan secara Daring yang disusun sesuai dengan KD. RPP tersebut menjadi pedoman guru dalam melaksanakan proses pembelajaran.

Hal di atas sesuai dengan apa yang dikemukakan oleh pak TP bahwa "perencanaan pembelajaran disusun dengan dengan kondisi pandemi sehingga menyesuaikan dengan kebutuhan dan kondisi sosial anak". Hal ini juga dipertegas kemudian oleh JU yang mengatakan: 
Perencanaan pembelejaran daring yang saya lakukan dilakukan dengan meringkas materi pembelajaran sesuai dengan buku paket dan LKP (Lembar Kerja Peserta didik), saya merancang materi semenarik mungkin agar peserta didik lebih mudah untuk memahami pembelejaran setelah itu saya memfoto materi kemudian mengirimkan melalui grup Whatsapp yang telah dibuat terlebih dahulu. Selain memfoto dan meringkas materi pembelajaran saya juga membuat video pembelajaran dengan materi yang berbeda-beda kemudian dikirim di Whatsapp grus kelas, begitupun dengan tugas-tugasnya dan dikumpulkan melalui Whatsapp.

RPP guru menggunakan beragam fitur aplikasi pembelajaran seperti Whatsapp dan Telegram. Dalam prakteknya, rencana dan aksi pembelajaran tidak sesuai. Banyak hambatan diantaranya adalah penyiapan bahan ajar. Selain RPP guru juga membuat video pembelajaran, dan terkadang menyita waktu dalam membuatnya. Ditambah lagi dengan keterampilan guru masih perlu dioptimalkan dalam menyusun dan mendesain video pembelajaran yang sistematis dan mudah dipahami.

Hasil wawancara di atas juga dikonfirmasi melalui hasil observasi bahwa sebelum melaksanakan pembelajaran guru diharapkan dapat membuat perencanaan pembelajaran. Dalam perencanaannya juga memasukkan komponen pembelajaran lain seperti penggunaan fitur Whatsapp, Telegram dan lain sebagainya. Fitur tersebut terintegrasi dalam dokumen pembelajaran.

Hambatan lainnya adalah manajemen waktu yang kurang baik dan persiapan waktu kelas yang kurang. Hal ini juga diperkuat oleh temuan yang mengatakan bahwa guru membutuhkan waktu lebih lama dalam mempersiapkan satu pembelajaran daring dibandingkan dengan pembelajaran tatap muka (Prasad et al., 2018). Untuk itu dalam membuat perencanaan pembelajaran, guru membutuhkan bantuan orang lain, guru juga harus mempertimbangkan resistensi atau gangguan terhadap teknologi yang digunakan. Sebagaimana terjadi pula ketimpangan aksesabilitas teknologi dengan berbagai persoalan termasuk bandwidth rendah dan kecepatan pemrosesan lambat serta mengalami kesulitan teknis dalam menyelesaikan tugas (Akçayır \& Akçayır, 2018).

\section{Proses pelaksanaan pembelajaran daring}

Pembelajaran dimaknai sebagai kegiatan belajar yang dilakukan oleh pembelajar dan guru (Ismail \& Aflahah, 2019). Pelaksanaan pembelajaran adalah upaya implementatif dari rencana pelaksanaan pembelajaran yang terdiri atas berbagai aktifitas pembelajaran seperti pendahuluan, inti, dan penutup. Untuk itu, 
perlu penguatan kemampuan guru dalam mengembangkan profesionalisme guru dalam menyusun instruksional (Knight, 2019).

Pada prakteknya, proses pembelajaran adalah pembuktian dan realisasi dari perencanaan. Pada proses tersebut dibutuhkan kemampuan dalam manajemen dan rekayasa perubahan perilaku belajar di dalam kelas, pencapaian target pembelajaran, budaya sekolah dan kolabaorasi guru dan peserta didik dalam melaksanakan pembelajaran (Desimone \& Katie, 2017). Dengan memahami kondisi dan budaya sekolah, guru diharapkan dapat menyesuaikan metode dan teknik pembelajarannya, termasuk mengelola proses pembelajaran daring.

Proses pembelajaran daring yang dilaksanakan oleh guru kelas di MIN 2 Kota Mataram terdiri dari beberapa proses, yaitu penyesuaian RPP dengan keadaan peserta didik, guru harus melakukan Analisa seberapa besar kemampuan peserta didik dalam memahami materi pelajaran, menentukan metode yang tepat sesuai dengan keadaan peserta didik yang belajar dirumah. Sebagai contoh dalam pembelajaran Matematika dan pembelajaran Agama Islam, memiliki berbagai hambatan seperti, pada saat guru menyampaikan materi hitungan tentunya menggunakan berbagai macam metode dan media pelajaran seperti membuat video pembelajaran, peserta didik dapat menyimak video yang ditayangkan.

Begitupun dengan materi pembelajaran Agama Islam, guru tidak hanya meringkas, memfoto materi pembelajaran yang kemudian dikirim di Whatsapp Group, tetapi guru kelas membuat video pembelajaran yang diperagakan. Materi dalam video tersebut menjadikan guru sebagai subjek video. Sebagai contoh dalam pembelajaran berwudhu dan lain sebagainya, sehingga peserta didik akan lebih mudah memahami materi pembelajaran tersebut. Penggunaan video dalam pembelajaran dapat meningkatkan aktivitas dan hasil belajar peserta didik (Yatri \& Pratiwi, 2017).

Hal di atas senada denga napa yang dikemukakan oleh JU sebagai berikut:

Setiap kali ingin memberikan tugas saya mefoto soal-soal itu yang ada di LKS, terkadang saya membuat sendiri soal-soal tersebut kemudian saya kirimkan melalui Whatsapp grup kelas ataupun menggunakan Telegram. Selain itu jika terkait dengan tugas-tugas dari mata pelajaran Agama Islam tentang hafalan surah-surah pendek, saya menyuruh mereka untuk membuatkan video merekam dirinya sendiri yang menghafal surahsurah pendek tersebut kemudian dikirim lewat Whatsapp grup kelas.

Untuk menguatkan pendapat informan di atas, kondisi pembelajaran yang diamati juga menerapkan proses pemberian tugas oleh guru kelas dengan cara 
mengirimkan foto soal-soal yang ada di LKS yang dibuat, kemudian guru kelas langsung mengirimkan di grup Whatsapp sesuai dengan waktu yang telah ditentukan oleh pihak madrasah. Kemudian peserta didik mengerjakan soal-soal sesuai dengan arahan dari guru kelas dengan batasan waktu tertentu. Setelah mengirimkan tugas di grup Whatsapp guru kelas terus tidak melepas begitu saja, guru memantau dan menanyakan perihal soal-soalnya yang dikirim apakah ada kesulitan atau tidak. Setelah itu untuk pengumpulan tugas dikumpulkan di sekolah sesuai dengan batasan waktu yang telah ditentukan oleh guru kelas

Kompleksitas aktivitas guru dalam melaksanakan pembelajaran daring mengindikasikan bahwa pembelajaran daring sebenarnya dihajatkan bagi level pendidikan yang lebih tinggi. Kendala lain yang dihadapi saat melaksanakan pembelajaran daring adalah kemampuan peserta didik dalam menafsirkan tugas yang diberikan guru. Walaupun dalam pendampingan belajar orang tua, namun tidak semua orang tua memiliki pengetahuan yang mumpuni dalam memfasilitasi dan mendampingi belajar anak di rumah.

\section{Evaluasi pembelajaran daring di MIN 2 Kota Mataram}

Penilaian merupakan salah satu komponen penting dalam proses pencapaian hasil belajar yang diinginkan. Penilaian menjadi kompas dan cermin bagaimana peserta didik belajar. Oleh karena itu, setelah merencanakan dan melaksanakan proses pembelajaran maka instruktur penilaian guru selaras dengan tujuan, kegiatan dan instrument penilaian (Bigs \& Tang, 2017).

Penilaian guru dapat bersifat sumatif dan formatif. Penilaian sumatif berkaitan dengan waktu pelaksanaan evaluasi yaitu di akhir unit pembelajaran. sedangkan penilaian formatif bertujuan untuk memantau pembelajaran peserta didik selama proses pembelajaran dan memberikan umpan balik yang berkelanjutan untuk membantu peserta didik meningkatkan pembelajaran mereka, termasuk menyelenggarakan evaluasi menggunakan online assessment.

Penilaian daring diyakini sebagai metode evaluasi yang efektif dan efesien (Bull \& McKenna, 2003). Peserta didik dapat menyesuaikan tes dengan waktu luangnya, dan mengulangnya dalam beberapa kali kesempatan. Penelitian sebelumnya juga menunjukkan bahwa penilaian daring dapat memperkaya pengalaman belajar peserta didik dengan mempromosikan keterlibatan aktif, merangsang interaksi dengan konten materi, diri sendiri, dan orang lain, meningkatkan motivasi peserta didik, dan mendorong peserta didik untuk 
bertanggungjawab (Xiong et al., 2015). Untuk itu evaluasi harus terencana dengan baik.

Evaluasi adalah kegiatan yang terencana untuk mengetahui keadaan suatu objek dengan menggunakan instrumen dan membandingkan hasilnya dengan tolak ukur untuk memperoleh simpulan (Sobry, 2021). Dalam melakukan evaluasi guru memberikan soal-soal kepada peserta didik yang dikirim melalui chat Whatsapp Group dan tidak hanya itu guru mengirimkan foto soal-soal yang ada sesuai dengan LKS. Ketika peserta didik mengerjakan tugas, guru kelas memberikan batasan waktu dalam mengerjakan maupun mengumpulkan tugas. Setelah memberikan batasan waktu dalam mengerjakan tugas, peserta didik mengumpulkan tugas di sekolah setiap hari jum'at ataupun hari sabtu, karena guru harus mengoreksi satu persatu tugas yang dikumpulkan oleh peserta didik. Terkadang ada peserta didik yang sama sekali tidak mengerjakan tugas karena asyik bermain game dan tidak di kontrol oleh orang tuanya di rumah karena orang tuanya juga sibuk bekerja sehingga peserta didik lupa untuk mengerjakan tugas.

Dari hasil temuan di atas peneliti dapat menyimpulkan bahwa hambatanhambatan dalam penerapan pembelajaran daring di MIN 2 Kota Mataram. Diantaranya adalah: (1) Guru mengalami kesulitan dalam mengkombinasikan dan mengintegrasikan keadaan peserta didik dalam proses pembelajaran. (2) Motivasi peserta didik untuk mengerjakan tugas tidak optimal tanpa pengawasan langsung dari orang tua, bahkan masih ada yang tidak mengumpulkan tugas sama sekali.

\section{Hambatan dominan dalam pembelajaran daring di MIN 2 Kota Mataram}

Berdasarkan paparan di atas, terdapat beragam hambatan dalam melaksanakan pembelajaran daring. Namun yang paling dominan adalah penguasaan guru dalam mengoperasikan e-learning, keterbatasan kuota internet, dan ketersediaan sarana pendukung, lebih jelasnya diuraikan sebagai berikut:

Pembelajaran daring membutuhkan internet untuk mengeksplorasi informasi atau sering disebut juga sebagai cybermedia (Syamsul, 2018). Selain itu, pembelajaran daring populis dengan istilah e-learning terdiri dari dua kata yaitu: e dan Learning. E merupakan singkatan dari elektronik yang berarti benda yang dibuat dengan menggunakan prinsip elektronika. Sedangkan Learning yang berarti pembelajaran atau belajar. Dengan demikian E-learning dapat diartikan sebagai proses belajar atau pembelajaran dengan memakai alat elektronik seperti komputer (Simanihuruk et al., 2019). 
Mengulik informasi mendalam tentang hambatan dominan yang dihadapi guru dalam melaksanakan pembelajaran daring, berikut petikan wawancara dengan pak TR, belaiu mengungkapkan bahwa:

Hambatan-hambatan yang dialami guru dalam penerapan pembelajaran daring yaitu: Pertama guru masih banyak yang belum bisa menggunakan aplikasi seperti E-Learning yang telah disiapkan oleh Kementerian Agama terkait dengan penerapan pembelajaran daring, sehingga guru dianjurkan untuk menggunakan aplikasi whats app ataupun telegram untuk mengirimkan video pembelajaran terhadap peserta didik. Kedua banyak guru yang lalai dalam mengirimkan materi pelajaran kepada peserta didik karena sering menunda-nunda waktu dalam membuat video, padahal sebelumnya telah dibuatkan jadwal khusus dalam membuat serta mengirimkan video pembelajaran sesuai dengan jadwal yang telah ditentukan oleh pihak madrasah. Ketiga ialah hambatannya tidak ada kuota internet untuk menghubungan jaringan agar peserta didik bisa melaksanakan pembelajaran daring. Hal ini menjadi kurangnya efektifitas dalam belajar peserta didik, ditambah lagi peserta didik yang sering sekali mengeluh sakit mata dan terkadang video pembelajaran dibuat oleh gurupun tidak maksimal akibat menunda-nunda waktu dalam merancang materi pelajaran yang akan dibuatkan video ini menjadi hambatan dalam penerapan pembelajran daring.

Selanjutnya, diwaktu yang berbeda, JU memaparkan kendala dominan dalam pelaksanaan pembelajaran daring yaitu sebagai berikut:

Hambatan yang terjadi pada saat penerapan pembelajaran daring ialah peserta didik sering merasa jenuh karena setiap hari belajar dengan menggunakan HP pada saat kegiatan belajar, sehingga berdampak pada nilai-nilainya menurun, tetapi tidak semua peserta didik hanya ada beberapa saja. Kemudian banyak peserta didik yang mengeluh sakit-sakit matanya akibat sering belajar menggunakan HP yang megakibatkan peserta didik malas untuk belajara, peserta didik juga sering tidak mengerjakan tugasnya akibat mereka menggunakan HP setiap saat yang seharusnya untuk digunakan untuk belajar melainkan untuk bermain game, dan ada juga peserta didik yang masih tidak memiliki Hp android untuk digunakan dalam belajar daring.

MIN 2 Kota Mataram telah menerapkan sistem pembelajaran daring. Dalam proses optimalisasi membutuhkan media elektronik dalam mengefesiensi pembelajaran. Akan tetapi ada kendala yang menjadi penghambat dalam menerapkan pembelajaran daring tersebut yaitu masih ada sebagian guru yang belum memahami dan menguasai aplikasi e-learning tersebut. Dengan adanya hambatan tersebut guru memutuskan untuk menggunakan aplikasi lain sebagai penunjang pembelajaran.

Hambatan dominan berikutnya adalah keterbatasan kuota internet. Dan handphone. Keterbatasan ini biasanya dialami dan dipertegas oleh pengakuan 
peserta didik, karena tidak sedikit peserta didiknya berasal dari kalangan menengah ke-bawah. Hambatan tersebut menjadikan kegiatan belajar mengajar tidak berjalan dengan lancar, karena keluhan dari guru maupun peserta didik yang tidak memiliki kuota dalam kegiatan belajar mengajar.

\section{Upaya Mengatasi Hambatan Guru Dalam Pembelajaran Daring Di MIN 2 Kota Mataram}

Dalam penerapan pembelajaran daring terdapat banyak sekali hambatanhambatan yang dialami oleh guru maupun peserta didik. Dengan adanya hambatan tersebut tentu pihak madrasah memberikan solusi yang terbaik dalam mengatasi hambatan tersebut. Beberapa solusinya adalah: (1) Pihak madrasah menyediakan sarana dan prasana untuk mengatasi hambatan dengan mengadakan kuota internet gratis dari pemerintah; (2) memberikan bantuan bagi peserta didik yang tidak memiliki HP Android, tidak hanya itu guru selalu memberikan semangat dan motivasi terhadap peserta didik yang sering mengalami kejenuhan dalam belajar daring, supaya peserta didik lebih semangat dalam belajar meskipun tidak belajar tatap muka seperti biasa, guru selalu menyajikan materi pelajaran dengan berbagai macam metode supaya kegiatan belajar mengajar tidak membosankan. Sebagaimana dikemukana oleh pak TR dan ibu JU:

Di MIN 2 Kota Mataram ini telah menerapkan pembelajaran daring selama masa pandemi ini, tentu selama dalam penerapan pembelajaran daring ini tidak terlepas dari berbagai hambatan-hambatan yang terjadi terhadap guru maupun peserta didik itu sendiri, selaku kepala madrasah di MIN 2 Kota Mataram mencari solusi yang tepat untuk mengatasi berbagai hambatan yang dialami oleh guru maupun peserta didik dengan cara memberikan sarana untuk mempermudah kegiatan belajar selama penerapan pembelajaran daring seperti; memberikan HP bagi peserta didik yang tidak memiliki HP android dan peserta didik yang tidak sama sekali memiliki HP. Kemudian mengedakan kouta gratis dari kementerian agama untuk guru dan peserta didik, untuk semua sarananya sudah terpenuhi oleh pihak madrasah.

Dalam mengatasi berbagai hambatan-hambatan yang terjadi dengan guru maupun peserta didik tersebut, untuk guru sendiri sebisa mungkin untuk merancang video pembelajaran maupun menyajikan materi pembelajaran semenarik mungkin agar peserta didik lebih semangat untuk belajar maupun mengerjakan tugas-tugas yang diberikan oleh guru. Kemudian guru menggunakan berbagai macam metode untuk agar peserta didik tidah merasa jenuh saat belajar sendirian di rumah. Guru senantiasa memberikan semangat dan motivasi dalam belajar walaupun dalam penerapan pembelajaran daring saat ini. 
Berdasarkan pernyataan di atas peneliti dapat menyimpulkan bahwa cara guru dalam mengatasi berbagai hambatan-hambatan penerapan pembelajaran daring yaitu; dengan cara merancang video pembelajaran, menyajikan materi pelajaran dengan menarik sehingga peserta didik tidak akan mudah merasa bosan pada saat belajar, selanjutnya guru selalu memberikan semangat dan motivasi untuk belajar, meskipun dalam kendaan pandemi saat ini. Tidak hanya itu saja guru juga menggunakan berbagai cara dan metode agar peserta didik semangat untuk belajar, kemudian hari pihak madrasahpun sudah memberikan sarana untuk melancarkan kegiatan pembelajaran daring dengan cara mengadakan kuota gratis pemerintah, dan memberikan HP bagi beberapa peserta didik yang tidak memiliki HP ataupun peserta didik tidak miliki HP android.

Merujuk pada berbagai literatur hasil penelitian sebelumnya, berbagai solusi yang dapat diterapkan dalam mengatasi pembelajaran daring diantaranya dengan mengkombinasikan model pembelajaran PBI (Problem Based Instruction) dengan media Whatsapp (Rosmiati \& Lestari, 2021). Demikian pula penyelenggaraan pembelajaran online membutuhkan biaya yang tidak kecil, butuh berbagai komponen pendukung seperti gadget, listrik, dan lain sebagainya. Untuk mengatasi hambatan tersebut, guru sebaiknya melaksanakan program belajar secara manual yaitu home visit yaitu kunjungan belajar dari rumah ke rumah (Atsani, 2020). Temuan di atas juga diperkuat oleh pandangan yang mengatakan bahwa bukan hanya dapat memotret kendala dalam perspektif peserta didik, namun dapat juga menyoroti aspek guru, melalui pembelajaran daring, guru dapat meningkatkan profesionalismenya dibidang teknologi, guru akan semakin terampil dalam mengoperasikan pembelajaran berbasis teknologi (Jamilah, 2020).

\section{SIMPULAN}

Berdasarkan hasil penelitian dan pembahasan di atas dapat disimpulkan bahwa terdapat berbagai hambatan dalam menerapkan pembelajaran daring di kelas V MIN 2 Kota Mataram sebagai berikut: (1) Guru membuat RPP daring namun tidak dapat menerapkannya secara optimal karena guru harus menyesuaikan dengan keadaan peserta didik; (2) Masih terdapat sebagian guru yang belum akrab dengan penguasaan teknologi informasi; (3) Sarana dan prasarana kurang memadai; (4) akses internet bagi peserta didik terbatas, artinya tidak semua peserta didik memiliki akses internet; (5) Minimnya ketersediaan anggaran. 
Dari berbagai kendala di atas, terdapat kendala dominan yang dihadapi guru yaitu optimalisasi penguasaan media pembelajaran daring. Sebagai upaya mengatasi kendala tersebut, guru dapat menggantikan media pembelajaran menggunakan aplikasi lain seperti telegram dan lain sebagainya. Adapun untuk mengatasi keterbatasan kuota dan HP, pihak sekolah menyediakan sarana pendukung tersebut. Selain itu, untuk mengurangi kebosanan peserta didik dalam belajar, guru tidak hanya menyajikan materi daring, tetapi juga memotivasi anak terus semangat belajar walaupun dalam keterbatasan.

\section{UCAPAN TERIMA KASIH}

Ucapan terima kasih ditujukan pada pengelola jurnal yang telah bersedia memberikan masukan dan arahan dalam penyempurnaannya. Selanjutnya kami ucapkan terima kasih kepada para pihak yang telah membantu penyelesaian artikel berikut yang telah memberikan bantuan dana dan pihak-pihak lainnya yang terlibat.

\section{DAFTAR PUSTAKA}

Afrizal. (2016). Metode Penelitian Kualitatif: Sebuah Upaya Mendukung Penggunaan Penelitian Kualitatif Dalam Berbagai Disiplin Ilmu. PT. Raja Grafindo Persada.

Akçayır, G., \& Akçayır, M. (2018). The flipped classroom: A review of its advantages and challenges. Computers and Education, 126, 334-345. https://doi.org/10.1016/j.compedu.2018.07.021

Asrul, \& Ranti, N. P. (2020). Hambatan dan solusi guru sekolah dasar terhadap pembelajaran daring selama masa pandemi Covid-19.1-17.

Atsani, L. G. M. Z. (2020). Transformasi media pembelajaran masa pandemi Covid19. Al-Hikmah: Jurnal Studi Islam, 1(1), 82-93.

Bigs, J. B., \& Tang, C. (2017). Teaching for Learning Quality in University (Open Unive).

Brown, M. G. (2016). Blended instructional practice: A review of the empirical literature on instructors' adoption and use of online tools in face-to-face teaching. The Internet and Higher Education, 31, 1-10. https://doi.org/10.1016/j.iheduc.2016.05.001

Bull, J., \& McKenna, C. (2003). A Blue Print for Computer-Assisted Assesment. Routledge.

Chaedar, A. (2015). Pokoknya Studi Kasus Pendekatan Kualitatif. PT. Kiblat Buku Utama.

Desimone, L. M., \& Katie, P. (2017). Instructional coaching as high-quality professional development. Theory Into Practice, 56(1), 3-12.

Handika, J. (2020). Pembelajaran Sains di era Akselerasi Digital. CV Media Grafika.

Ismail, M., \& Aflahah. (2019). Konsep Dasar Belajar dan Pembelajaran. Duta Creative.

Jamad, M. (2020). Pembelajaran di tengah pandemi Covid-19. In Goresan Pena Guru Bahasa Kala Pandemi Corona. Omera Pustaka.

Jamilah. (2020). Guru profesional di era new normal: Review peluang dan tantangan dalam pembelajaran daring. Premiere Educandum: Jurnal Pendidikan Dasar Dan Pembelajaran, 10(2), 238-247. https://doi.org/10.25273/pe.v10i2.7494 
Khurriyati, Y., Setiawan, F., \& Mirnawati, L. B. (2021). Dampak pembelajaran daring terhadap hasil belajar siswa MI Muhammadiyah 5 Surabaya. Jurnal Ilmiah Pendidikan Dasar, 8(1), 91-104. https://doi.org/10.30659/pendas.8.1.91-104

Knight, J. (2019). Instructional coaching for implementing visible learning: A model for translating research into practice. Education Science, 9, 1-16.

Kustiana, S., \& dkk. (2021). Sebuah Buku Tentang Covid-19. Tidar Media.

Kusumadewi, R. F. (2015). Pembiayaan pendidikan di Indonesia. Jurnal Ilmiah Pendidikan Dasar, 2(1), 43-64.

Lismina. (2018). Pengembangan kurikulum di sekolah dan perguruan tinggi. Uwais Insprirasi Indonesia.

Malik, A., \& Afandi, M. (2020). Peningkatana disiplin dan prestasi belajar PAI menggunakan model Quantum Teaching kelas VII MTs Al-Ishlah Binabaru. Jurnal Ilmiah Pendidikan Dasar, 7(1), 60-67. https://doi.org/10.30659/pendas.7.1.60-67

Nasution, Y. S., Syahputra, E., \& Mulyono. (2020). The development of learning instrument using Problem Based Learning model to improve critical thinking of junior high school students. BirLe-Journal, 3(3), 1501-1508. https://doi.org/10.33258/birle.v3i3.1223

Prasad, P. W. C., Maag, A., Redestowicz, M., \& Hoe, L. S. (2018). Unfamiliar technology: Reaction of international students to blended learning. Computers \& Education, 122, 92-103. https://doi.org/10.1016/j.compedu.2018.03.016

Protokol Percepatan Penanganan Pandemi Covid-19 (Corona Virus Disease 2019). (2019). Satuan Tugas Penanganan Covid-19. covid19.go.id

Rasheed, R. A., Kamsin, A., \& Abdullah, N. A. (2020). Challenges in the online component of blended learning: A systematic review. Computers \& Education, 144, 1-17. https://doi.org/10.1016/j.compedu.2019.103701

Rigianti, H. A. (2020). Kendala pembelajaran daring guru sekolah dasar di Kabupaten Banjarnegara. Jurnal Pendidikan Dan Pembelajaran Ke-SD-An, 7(2), 297-302. https://doi.org/10.31316/esjurnal.v7i2.768

Rimbarizki, R., \& Susilo, H. (2017). Penerapan pembelajaran daring kombinasi dalam meningkatkan motivasi belajar peserta didik PAKET C Vokasi di Pusat Kegiatan Belajar Masyarakat (PKBM) Pioneer Karanganyar. J+Plus Unesa, 6(2), 1-12.

Rosmiati, U., \& Lestari, P. (2021). Inovasi model Pembelajaran PBI (Problem Based instruction) berbasis Whatsapp sebagai langkah solutif pembelajaran di masa pandemi Covid-19. Jurnal Nasional Pendidikan Matematika, 5(1), 188-197. https://doi.org/10.33603/jnpm.v5i1.3708

Safford, K., Stinton, J., \& Julia. (2016). Barriers to blended digital distance vocational learning for non-traditional students. British Journal of Educational Technology, 47(1), 135-150.

Simanihuruk, L., Simarmata, J., Sudirman, A., Hasibuan, M. S., Safitri, M., Sulaiman, 0. K., Ramadhani, R., \& Sahir, S. H. (2019). E-Learning: Implementasi, Strategi dan Inovasinya. Yayasan Kita Menulis.

Sobry, M. (2021). Strategi Pembelajaran. Penerbit Adab.

Suardi, M. (2018). Belajar dan Pembelajaran. Deepublish.

Sudarsana, I. K. (2020). Pembelajaran dalam jaringan dan upaya memutus pandemi Covid-19. In Covid-19 Perspektif Pendidikan (pp. 1-10). Yayasan Kita Menulis.

Syamsul, A. (2018). Jurnalistik Online (Panduan Mengelola Media Online). Nuansa Cendekia.

Tim PGSD C. (2017). Pembelajaran Seni Budaya SD I Pembelajaran Seni Tari di Indonesia dan Mancanegara. UMM Press.

Wicaksono, V. D., \& Rachmadyanti, P. (2017). Pembelajaran blended learning melalui Google Classroom di sekolah dasar. Prosiding Seminar Nasional Dan Call for 
Papers Pendidikan 2017 (PGSD UMS \& HDPGSDI Wilayah Jawa), 513-521.

Widyantara, I., \& Rasna, I. (2020). Penggunaan media Youtube sebelum dan saat pandemi Covid-19 dalam pembelajaran keterampilan berbahasa peserta didik. Jurnal Pendidikan Dan Pembelajaran Bahasa Indonesia, 9(2), 113-122.

Xiong, Y., Li, H., Kornhaber, M., Suen, H., Pursel, B., \& Goins, D. D. (2015). Examining the relation among student motivation, engagement, retention in MOOC: A structural equation modelling approach. Global Education Review, 2(3), 23-33.

Yatri, I., \& Pratiwi, L. (2017). Peranan media video dalam meningkatkan aktivitas siswa pada pembelajaran IPS di kelas V SDN Mampang Prapatan 02 Pagi. Jurnal Ilmiah Pendidikan Dasar, 4(2), 70-80. https://doi.org/10.30659/pendas.4.2.70-80

Zulkifli, Fatmawati, Yuliana, Putri, A. N., Albakri, S. A., Adyanti, K. A., Fauziah, N., Multiani, Muftiara, A. W., Sanusi, I., Tahir, R. A., Idul, M., Awal, M. R., Saripa, Hafid, R., Rahman, N., Irnawati, \& Herdah. (2020). Berkarya Bersama di Tengah Covid-19. IAIN Parepare Nusantara Press.

Conflict of Interest Statement: The authors declare that the research was conducted in the absence of any commercial or financial relationships that could be constructed as a potential conflict of interest. 